\title{
COMMENTS
}

\section{THE VOICE OF A CHILD: INDEPENDENT LEGAL REPRESENTATION OF CHILDREN IN PRIVATE CUSTODY DISPUTES WHEN SEXUAL ABUSE IS ALLEGED}

\author{
KERIN S. BISCHOFF†
}

Children are our most precious resource, and it is fundamental that they have a chance to be brought up in an environment where they are not abused or neglected. To that end, it is the duty of our courts to use every available legal means to see that such a goal be attained. ${ }^{1}$

Children represent the future of society and the promise of humankind. Yet children are vulnerable, impressionable, and in need of guidance. When court proceedings will immutably alter childrens' lives, their interests must be voiced. ${ }^{2}$

"The right to representation by counsel is not a formality . . . it is of the essence of justice." 3 Children are now guaranteed legal representation in juvenile delinquency proceedings. Children in stateinitiated investigations of suspected abuse are also provided with counsel, based on the premise that a child is an independent individual with the right to articulate her own interests in matters so fundamentally affecting the quality of her life. ${ }^{4}$ When allegations of sexual abuse occur during a private custody battle, however, independent representation for the child is not required and is rarely provided. While some children's rights advocates urge requiring counsel to

† B.S. 1988, Bowling Green State University; J.D. Candidate 1991, University of Pennsylvania. This Comment is dedicated to Susan Knecht Smith, with many thanks.

1 C.J.(S.)R. v. G.D.S., 701 S.W.2d 165, 169-70 (Mo. Ct. App. 1985).

2 See generally J. Wallerstein \& S. Blakeslee, Second Chances: Men, Women \& Children a Decade After Divorce (1989) [hereinafter Second Chances] (exploring the psychological impact of divorce on children); Foster \& Freed, $A$ Bill of Rights for Children, 6 FAM. L.Q. 343 (1972) (offering a framework of rights incorporating minors' expectations).

3 Kent v. U.S., 383 U.S. 541, 561 (1966).

4 See Stapleton v. Dauphin County Child Care Serv., 228 Pa. Super. 371, 381382, 324 A.2d 562, 568 (1974). 
represent children in all disputed custody cases, ${ }^{5}$ little attention has been given to the special concerns raised by allegations of incest during custody disputes.

This Comment argue:s that allegations of sexual abuse made during custody disputes raise a particular need for independent legal representation of children. The predominant current legal standard, jidicial discretion, often allows this need to go unmet. Independent legal representation of all potential victims of sexual abuse is essential to protect effectively the "best interests" of these children.

\section{Current State of the Law Regarding Children's Advocates in Private Custody Disputes}

In general, present law does not require independent legal representation of children in private custody disputes. When parents divorce or separate, the court is vested with the authority to make a determination ${ }^{6}$ regarding the custody of children. ${ }^{7}$ The virtually universal standard mandated by legislatures to determine child custody disputes is the "best interests" standard. 8 While the substantive law of custody gives children a right to a determination made in

5 Many of the sources cited in this Comment argue for appointing a guardian ad litem or a child advocate in all custody or disputed custody cases. While accepting the validity of these arguments, the author views those situations involving allegations of sexual abuse to implicate far more serious concerns.

6 The court has jurisdiction to consider all issues surrounding the custody of children whenever parents appear in court for a divorce, annulment, or separation. See e.g., Cal. Civ. Code \$ 4600 (West 1983 \& Supp. 1989); ConN. Gen. Stat. AnN. $\S 466-56$ (West 1986). Courts ty'pically incorporate the parties' privately reached custodial agreement into the judgment. However, the court's best interests inquiry is not precluded by a private agreernent. See Mnookin \& Kornhauser, Bargaining in the Shadow of the Law: The Case of Divorce, 88 YALE L.J. 950, 955 (1979).

$7 \mathrm{~A}$ "child" is a person who has not reached the age of state-determined civil majority, generally eighteen years. See Soler, Costello \& O'Hearn, Legal Rights of Children in the United States of America, in LAW AND THE STATUS OF THE CHILD 675, 683 (A. Pappas ed. 1983) [hereinafter Legal Rights of Children]. Under the common law, a child under the age of seven was deemed incapable of forming the requisite intent to commit a crime. See id. at 683 . Notably, the seven-year cut-off is often used as the age at which children are deemed to be competent to direct their attorneys. See, e.g., Juvenile Law Center of Philadilphia, Model of Representation in Dependent CourT 7 (1986) ("When representing clients under age seven, we will assert rights on our client's behalf.").

8 See e.g., Cal. Crv. Code $\S 4600$ (b) (West 1983 \& Supp 1989); Conn. Gen. Stat. ANN. § 466-54 (West 1986); D.C. CodE ANN. §§ 16-911(a)(5), -914(a) (1981); Haw. Rèv. Stat. § 571-46(1) (1985); Ky. Rev. Stat. AnN. § 403.270 (Michie/Bobbs-Merrill 1984); Mass. Ann. Laws ch. 208, § 31 (Law. Co-op 1989); N.Y. Dom. Rel. Law § 240 (McKinney 1986 \& Supp. 1990); see also UNIForm MARRIAGe \& DivorCe ACT $\$ 402$ (1974); Bazemore v. Davis, 394 A..2d 1377, 1383 (D.C. 1978) (holding that child's best interests are sole criterion in custody dispute between [biological] parents). 
their "best interest," children generally do not have the right to have their views regarding their interests presented to the court. ${ }^{9}$

Recent standards issued by the American Bar Association would require the appointment of independent counsel in custody cases. ${ }^{10}$ Only two states, however, mandate the appointment of a representative in all divorce-related custody disputes. ${ }^{11}$ In most states, the appointment of a representative for children in private custody disputes is a matter of judicial discretion, either by statute ${ }^{12}$ or by the judge's inherent power. ${ }^{13}$

9 See Note, Due Process for Children: A Right to Counsel in Custody Proceedings, 4 N.Y.U. Rev. L. \& Soc. Change 177, 177 (1974) [hereinafter Due Process].

10 See A.B.A.-I.J.A. Standards Relating to Counsel for Private Parties (1980), reprinted in Children's Rights Chronicle, Dec. 1983, at 3; see also A Divorce Reform Act, 5 HARv. J. on LEGIs. 563, 583 (1968) (model act for child advocacy drafted by the Legislative Research Bureau of Harvard Law School which would require the appointment of independent counsel for all children whose rights might be affected in a divorce proceeding).

11 See N.H. Rev. Stat. Ann. § 458:17-a (Supp. 1989); Wis. Stat. ANN. § 767.045 (West 1981); Lane, The Guardian ad Litem in Divorce Cases, in Foundations of Child ADvocacy 161, 164 (D. Bross \& L. Michaels eds. 1987) (noting that Wisconsin and New Hampshire are the only two states which require the appointment of a guardian ad litem). Neither of these statutes makes special provisions for allegations of sexual abuse; counsel is provided in all disputed custody cases.

12 See, e.g., Cal. Crv. Code $\S 4606$ (West 1983 \& Supp. 1989) (providing for appointment of counsel upon court finding that appointment would be in child's best interests); Conn. Gen. Stat. ANN. § 466-54 (West 1971) (same); D.C. Code ANn. § 16-918(b) (1981) (same); HaW. Rev. Stat. \$ 571-46(8) (1985) (providing for appointment of guardian ad litem); MASs. ANN. LAws. ch. 215, § 56A (Law. Co-op. 1986) (providing for appointment of guardian ad litem for investigative purposes); N.Y. JuD. LAw § 249 (McKinney 1983) (providing for appointment of law guardian where child is party to certain proceedings if child is sought to be placed in protective custody); WASH. REv. CODE ANN. $\$ 26.09 .110$ (1986) (allowing for appointment of attorney if in child's best interests); WIS. STat. ANN. § 767.045 (West 1981) (allowing for appointment of attorney where court has reason for "special concern"). States are split as to whether or not the appointed person must be an attorney. The Uniform Marriage and Divorce Act permits the appointment of an attorney in private custody disputes to act as an advocate on behalf of the child. See UNIF. MarRIAGE \& Drvorce ACT $\$ 310,9 A$ U.L.A. 443 (1987). States may attempt to follow a policy of representation although the statutory language is permissive. See Lane, supra note 11, at 164. But see Foster \& Freed, supra note 2, at 355 n.40 (stating that while Dom. Rel. Law. § 215-c, enacted in California, Iowa, Oregon, and New York, authorizes the appointment of a guardian in divorce cases, such authority is rarely exercised).

13 See, e.g. Villareal v. State Dep't of Transp., 160 Ariz. 474, 481, 774 P.2d 213, 220 (1989) (stating that to ensure protection of rights of children, a trial judge may, upon his or her own motion, appoint a guardian ad litem); Gardner v. Gardner, 545 So.2d 339, 340 n.1 (Fla. Dist. Ct. App. 1989) (stating that in a custody case, the trial court has the option of appointing guardian ad litem if circumstances demand it); In re Marriage of Strauss, 183 Ill. App. 3d 424, 539 N.E.2d 808, 811 (1989) (holding that the courts have inherent power to appoint guardian ad litem for minors' interest in litigation); Parrillo v. Parrillo, 495 A.2d 683, 686 (R.I. 1985) (stating that "[i]t is well 
Statutes granting discretionary power typically permit a judge to appoint a guardian ad litem $^{14}$ or an attorney when the court determines that such appointment would be in a child's "best interests" during custody, support, and visitation proceedings. ${ }^{15}$ This standard is inherently indeterminate. Statutes may specify factors for consideration, ${ }^{16}$ but a judge's discretion in determining what constitutes a child's best interests is accorded great latitude. When evidence is contradictory, as it typically is in sexual abuse cases, the trial judge is

settled that the trial justice has the inherent power to appoint a guardian ad litem whenever there are interests of a minor to be protected"). The statutes merely supplement the court's inherent equity jurisdiction and do not displace it. See Due Process, supra note 9, at 179 n.13.

14 A guardian ad litem is generally defined as "a person invested during a legal proceeding with the power and duty to protect the rights and interests of a child (or an incompetent) involved in litigation." Davidson, The Guardian Ad Litem, CHILDREN TODAY, Mar.-Apr. 1981, at 1. There is no consensus as to the duties of the guardian ad litem. See id. The child advocate traditionally is granted some discretion to determine what the child's best interests may be. See Genden, Separate Legal Representation for Children: Protecting the Rights and Interests of Minors in Judicial Proceedings, 11 HaRv. C.R.-C.L. L. REv. 565, 588 (1976); infra text accompanying notes 51-67.

15 See, e.g., Cal. Crv. Code $\S 4606$ (West 1989) (providing that in a proceeding in which custody is an issue, the court may, "if it finds it would be in the best interests of the minor child," appoint a guardian ad litem). Other statutes have enunciated this "best interests" standard in different ways. See, e.g., N.D. CENT. CoDE § 14-09-06.4 (1981) (providing that a guardian ad litem may be appointed where there is "special concern as to the future of the minor children"); OHIO R. Crv. P. § 75(B)(2) (Anderson 1989) (providing for the guardian ad litem when "essential to protect the child's interests").

The "best interests" standard is vague because society lacks a consensus about the determining values which define what is "best." The standard is even more difficult because unlike traditional litigation based on past conduct, a best interests analysis requires a prediction of future behavior. See Lane, supra note 11, at 176 (noting that continued use of the best interest standard promotes the denial of a child's due process right); Mnookin, Child-Custody Adjudication: Judicial Functions in the Face of Indeterminacy, 39 LAw \& ConTemp. Probs. 226, 258-59 (1975) (noting that the determination of what is "best" or "least detrimental" for a child is usually speculative).

16 See e.g., Unif. Marriage \& Divorce Act § 402, 9A U.L.A. 561 (1987) (specifying parent's wishes as to custody, child's wishes as to custodian, child's interaction with parents, siblings, and others who may significantly affect best interests, child's adjustment to home, school, and community, and mental and physical health of all individuals involved, all taken into consideration); CoLo. Rev. STAT. § 14-10-124 (Supp. 1984) (Court shall consider all relevant factors including [those of UMDA \$402] and the ability of the custodian to encourage child's relationship with noncustodial parent); 1984 MiNN. Laws 518.17 Subdiv.1 (including wishes of parents, reasonable preference of child if deemed old enough, continuity of environment, and cultural background); $c f$. ALA. CODE § 30-3-1 (1983) (articulating standard as custody that may seem right and proper having regard to parents' prudence and moral character). 
the sole evaluator of the credibility of evidence and subsequent review presumes reasonableness. ${ }^{17}$

Some courts have recognized the need for independent counsel in particularly bitter and protracted custody proceedings. ${ }^{18}$ Divorced or divorcing parents' hostility toward one another may overshadow concern for the child's interests; as a result, the children's rights likely will not be fairly represented by the parents' counsel. ${ }^{19}$ Appointing a legal representative "assure[s] that one" voice will be raised in sole representation of the best interests of th[e] minor child."20

Operating under a discretionary statute, the Minnesota Court of Appeals found a trial court to have erred by failing to appoint a representative for two teenage girls in a custody suit in which sexual abuse by the step-father was alleged. ${ }^{21}$ The court recognized that when physical and emotional safety are in question, the interests of children are different from their parents and will not adequately be represented without "vigorous, independent representation of the children by counsel acting only in their interest."22

Similarly, a Missouri Court of Appeals held that it is an abuse of discretion not to appoint a representative when the choice of custodian is at issue and the "court has knowledge, from the pleadings or from any other source, that the children ... have been, or are being, abused."23

When the sexual molestation of a child is even a remote possibility, allegations of sexual abuse should automatically evoke the "special concern" necessary under a discretionary standard to compel the appointment of an independent representative. Because of the com-

17 See Atkinson, Criteria for Deciding Child Custody in the Trial and Appellate Courts, 18 FAM. L.Q. 1, 40 (1984) (describing a recent study which found that 30 states' appellate courts will affirm a trial court's custody decision unless it is a "clear abuse of discretion" or is "against the manifest weight of the evidence").

18 See, e.g., Yontef v. Yontef, 185 Conn. 275, 284, 440 A.2d 899, 904 (1981) (stating that the better course is to appoint independent counsel in seriously contested cases); Gennarini v. Gennarini, 2 Conn. App. 132, 477 A.2d 674, 675 n.3 (1984) (same).

19 See Martinez v. Martinez, 101 N.M. 493, 496, 684 P.2d 1158, 1161 (1984) (stating that when a child's welfare is at stake, the court would carefully review the record to ensure the child's interests were protected); Higgins v. Higgins, 629 S.W.2d 20, 22 (Tenn. Ct. App. 1981) (stating that in cases of intense hostility, children should have the benefit of independent counsel).

20 Clark v. Clark, 358 N.W.2d 438, 441 (Minn. Ct. App. 1984).

21 See M.M. v. R.R.M., 358 N.W.2d 86, 89 (Minn. Ct. App. 1984).

22 Id. at 89.

23 C.J.(S.)R. v. G.D.S., 701 S.W.2d 165, 169 (Mo. Ct. App. 1985).' 
peting notions of parens patriae and family autonomy, ${ }^{24}$ and the skepticism with which such allegations tend to be received by judges, however, this is not the case. Possible sexual abuse in a custody dispute does not uniformly trigger the appointment of counsel. Discretion allows some children who may have been sexually abused to go unrepresented. ${ }^{25}$

For example, in Sucher v. Sucher, ${ }^{26}$ a Minnesota appeals court upheld a trial court's refusal to appoint a guardian ad litem to represent three children in a custody battle. ${ }^{27}$ Despite allegations and some evidence of sexual abuse, the trial judge's failure to appoint a representative was held not to be an abuse of discretion. ${ }^{28}$ The child's story vacillated during an in camera interview and was therefore considered insufficient evidence to trigger the discretionary standard. ${ }^{29}$ While the child's role in this case was critical, counsel was denied based on the court's opinion that all the circumstances of the children had been fully litigated and that there were no alternatives which a guardian could have presented. ${ }^{30}$

\section{Why REQUIRE INDEPENDENT REPRESENTATION?}

Children must be provided with independent representation whenever allegations of sexual abuse are made because neither the judge nor the child's parents can adequately represent the child's interests. For the child, fundamental bodily and psychological integrity is at stake. "Independent representation by counsel [whenever the child's welfare is at stake] is the most significant and practical reform that can be made in the area of children and the law ... reform should be directed at [permitting] all interested partiesincluding children-to have independent counsel."31

As stated earlier, the substantive law guarantees all children in divorce cases the right to custody determinations made in their best

24 See discussion infra notes 68-94 and accompanying text.

25 See Who's Taking Care of tire Children? They May Need Counsel, CaL. LAw., Nov. 1987, at 12 [hereinafter Who's Taking Care] (stating that many judges, while authorized under California Civil Code $\$ 4606$, are reluctant to appoint attorneys for children, and adding that children often go unrepresented for want of available attorneys).

26416 N.W.2d 182 (Minn. Gt. App. 1987).

27 See id. at 185.

28 See id.

29 See id. at 183.

30 See id. at 185 (stating that foster care was the only alternative which a guardian could have presented).

31 Foster \& Freed, supra note 2, at 356. 
interests. ${ }^{32}$ The resolution of sexual abuse allegations will significantly shape the judge's assessment of the child's best interests. ${ }^{33}$ Yet the difficulties of proving sexual abuse ${ }^{34}$ are exacerbated by the divorce context and, therefore, abuse is often not legally established despite significant physical and psychological evidence. ${ }^{35}$ The ramifications of an erroneous decision-either ordering continued contact when a child is in actual jeopardy ${ }^{36}$ or constraining the relationship with a falsely accused parent ${ }^{37}$-make improved procedural standards at both the fact-finding and disposition stages essential in order to meet the statutory best interests mandate. ${ }^{38}$

Mandatory legal representation will ensure that the child's voice is heard. ${ }^{39}$ Representation is the sole procedure which assures that

32 See supra notes 6-9 and accompanying text.

33 See e.g., MD. FaM. LAw Code ANs. \$ 9-101 (Supp. 1989) (stating that unsupervised visitation and custody shall be denied to a party whom the court finds has abused a child, unless it is specifically found that there is no likelihood of further abuse).

34 Sexual abuse is difficult to prove because of the lack of corroborating witnesses, the victim's age, real and perceived problems in the credibility and competency of the child witness, clashes with the defendant's sixth amendment confrontation rights, and various cultural prejudices. See Apel, Custodial Parents, Child Sexual Abuse, and the Legal Systems: Beyond Contempt, 38 AM. U.L. REv. 491, 495-501 (1989); Keating, Children in Incestuous Relationships: the Forgotten Victims, 34 Loy. L. REv. $111,112-113$ (1988).

35 See Keating supra note 34, at 113-15 (stating that societal disbelief of the frequency of incest leads to judicial prejudice against accusing parents); see also infra text accompanying notes 101-04.

36 See Goldson, Child Development and the Response to Maltreatment, in Foundations of Child Advocacy 3, 13 (D. Bross \& L. Michaels eds. 1987) (noting common symptoms of withdrawal, self-abusive behavior, and internalized guilt resulting from disruption of normal psychological development); Kerns, The Pediatric Perspective, in Foundations of Child Advocacy, supra, at 23, 33 (stating that the psychological impact of sexual abuse ranges from acute trauma to the catastrophic and continuing developmental damage associated with continued incest).

37 See Second Chances, supra note 2, at 257 (recognizing the importance of maintaining two parents in the postdivorce family for the child's self-esteem and psychological well-being).

38 See Besharov, The Need to Narrow the Grounds for State Intervention, in Protecting Children from Abuse \& Neglect: Policy and Practice 47 (C. Thomas ed. 1988), reprinted in Child ABuse and Neglect 32, 36 (American Bar Ass'n. Nat'l Legal Resource Center for Child Advocacy and Protection eds. 1989); Genden, supra note 14, at 565 (noting that children's rights and interests are jeopardized when their best interests are determined without an independent advocate).

39 See Hansen, Guardians Ad Litem in Divorce and Custody Cases: Protection of the Child's Interests, 4 J. FAM. L. 181, 184 (1964) (discussing the Milwaukee Family Court system of appointing a guardian ad litem whenever custody is disputed and stating that having an advocate ensures court concern for the rights of children); $c f$. Who's Taking Care, supra note 25, at 12 (noting the perception of a Juvenile Court 
all matters of law will be available for the determination of the child's best interests. ${ }^{40}$ Without independent representation, the child, whether an actual victim of incest or not, risks needless abuse by the legal system charged to protect her best interests. Even if sexual abuse is not ultimately proven, ${ }^{41}$ the allegations themselves generate the need for representation because of the physical, psychological, and emotional probing of the fact-finding process. Any court adjudicating claims of sexual abuse without the participation of the child's advocate is relying on indirect, secondary evidence from parents, psychologists, and physicians. It is curious that when the potential harm to a child is so great, the judicial system would grant such importance to secondary evidence "when direct evidence is so easily obtainable. The best interests of a child can best be determined on the basis of objective, independent evidence . . . made available to the court [by] independent counsel." 42

The family court forum in which a judge considers allegations of sexual abuse made during divorce proceedings poses unique problems for the sexually abused child which necessitate according the child the extra procedural protection of a voice. ${ }^{43}$ Family courts are traditionally concerned with the equitable distribution of property and the reasonable access of both parents to their children. In fact, good faith allegations are insufficient summarily to halt continued contact with an alleged abuser. In "normal" divorce cases, preserving the continued contact of children with both parents is justifiable. . When a child is subjected to sexual molestation, however, continued contact is exceedingly harmful. ${ }^{44}$

Sucher $v$. Sucher ${ }^{45}$ demonstrates the potential dangers of a system in which appointment of independent representation is discretionary. The trial judge is not in a position to determine whether the

Commissioner that an advocate is needed when there are serious allegations of child abuse or when a controversial issie such as religious lifestyle threatens to overwhelm the child's interests).

40 See Due Process, supra note 9, at 185.

41 Commentators have observed that in many cases "presexual conditioning," a precursor to molestation, has taken place, even if actual sexual abuse has not yet occurred. See Walker \& Edwall, Domestic Violence and Determination of Visitation and Custody in Divorce, in Domestic Violence on Trial 127, 136 (D. Sonkin ed. 1987).

42 Inker \& Perretta, $A$ Child's Right to Counsel in Custody Cases, 5 Fam. L. Q. 108, 115 (1971).

43 See Keating, supra note 34, at 112 (noting that "[s]uch courts are set up to compromise and settle difficulties between two spouses").

44 See id.

45416 N.W.2d 182 (Minn. Ct. App. 1987). See supra notes 26-30 and accompanying text for discussion. 
child's circumstances, from the child's point of view, have been fully litigated. Rather, the advocate for the child, who is obligated to represent the child's interests, should make this determination. As the court stated in M.M. v. R.R.M., ${ }^{46}$ when "the missing element [is] vigorous, independent representation of the children by counsel," the record available for the trial judge will be "woefully incomplete."47

Finally, the discretionary standard is an inadequate safeguard when the consequences of a wrong decision are as devastating as those following incest. ${ }^{48}$ The legal representation of children is one affirmative step that can help the legal system operate in favor of abused children. While independent legal representation does not promise a complete solution to the dilemmas posed by sexual abuse allegations in divorce cases, the appearance of an attorney for the child may help a judge make "reasoned determinations of fact and ... disposition." 49 Suspected victims of sexual abuse need the "assistance of counsel to cope with problems of law, to make skilled inquiry into the facts, [and] to insist upon regularity of the proceedings." 50 In order to determine the best interests of children, the child's voice must be heard in all cases in which sexual abuse is alleged.

\section{The Role of the Child's Representative}

Ambiguity about the attorney's role in family litigation has emerged as an important issue in recent years. ${ }^{51}$ The role of chil-

46358 N.W.2d 86 (Minn. Ct. App. 1984).

47 Id. at 89 .

48 The effects of incest follow its victims into adulthood: creating cynical, troubled, and possibly dangerous adults and perpetuating a vicious cycle as the adults who were child-victims become offenders. See supra note 36 . It is only by breaking the cycle of grossly inadequate parent-child relationships that society stands to gain capable parents for the future. See J. Goldstein, A. Freud \& A. Solnit, Beyond THE BeST INTERESTS OF THE ChILd 7 (1983). Teaching children that the abuser will be sanctioned helps to break the cycle. Acting to ensure the proper adjudication of allegations of sexual abuse is not merely an act of humane concern for children, but also an act of enlightened societal self interest. See Delaney, The Battered Child and the Law, in Helping the Battered Child and His Family, 187, 193 (C. Kempe \& R. Helfer eds. 1972) [hereinafter Helping the BAtTEREd Child]

49 In re Gault, 387 U.S. 1, 40 (1967) (quoting N.Y. Family Court Act $\$ 241$ with approval and holding that a juvenile has a right to counsel in a serious delinquency proceeding) (discussed infra at notes $117-22$ and accompanying text).

50 Id. at 36.

51 See Isaacs, The Role of the Lawyer in Child Abuse Cases, in Helping the BatTered CHILD, supra note 48, at 225 (stating that acceptance of social work techniques and objectives in the judicial process has created much uncertainty as to the role of counsel in family litigation). 
dren's counsel is often undefined and, consequently, hotly disputed. ${ }^{52}$ Should she play the role of a guardian ad litem, who determines what is best for a child, ${ }^{53}$ or that of an advocate, who is obligated to present the wishes of her client? Also, should the child's representative, regardless of role, be required to be an attorney?

In order to ensure that the child's voice is heard in court, a representative should be an advocate who will advance the child's position and not make independent judgments of the child's best interests. ${ }^{54}$ An advocate, unlike a traditional guardian ad litem, ${ }^{55}$ insures that the child's voice is heard with full force in legal proceedings. To be effective, such an advocate should also be a lawyer. ${ }^{56}$ The following credo characterizes the role the attorney should play:

52 See, e.g., Redeker, The Right of an Abused Child to Independent Counsel and the Role of the Child Acvocate in Child Abuse Cases, 23 VILL. L. REv. 521, 539 (1978) (arguing that the guardian ad litem representation of state-determined "best interests" does not fulfill the child's need for counsel); Representing Dependent Children, CHILDREN's RIGHTs Chronicle, Dec. 1983, at 1 (discusising the lack of a clear model of representation in dependency cases).

53 See supra note 14 (defining guardian ad litem).

54 See Redeker, supra note 52, at 539-42 (advocating the need for legal counsel representing the child, and criticizing the concept of guardians ad litem); Genden, supra note 14, at 588-89; see also Bross, An Introduction to Child Representation, in Foundations of Child Advocacy 85, 86 (D. Bross \& L. Michaels eds. 1987) (noting that confusion as to the role of the attorney, even when the child cannot express her wishes is not justified, since "[i]t is no longer a question that objective standards can be established for representation of incompetent adults or other individuals"). Even when a client is too young to direct an attorney, the closest approximation of a normal attorney-client relationship, uninfluenced by third parties, best achieves the desired representation. See Comment, Speaking For a Child: The Role of Independent Counsel for Minors, 75 CaLIF. L. Riv. 681, $701-05$ (1987) (advocating a doctrine of substituted judgment whereby an attorney focuses on what the particular child, if mature, would desire).

55 See Note, Lawyering for the Child, 87 YALE L. J. 1126, 1140-41 (1978) (noting that the traditional guardian ad litem is a nonadvocate representative, more properly termed an investigator).

56 While not dismissing those child advocacy programs which have utilized nonlawyers, see, e.g., Blady, Special Child Advocates: A Volunteer Court Program, CHILdren ToDAY, May-June 1981, at 2 (discussing the benefits of court appointed special advocate volunteer programs in representing children); Comment, The Non-Lawyer Guardian ad Litem in Child Abuse and Neglect Proceedings, 58 WASH. L. Rev. 853, 864-67 (1983) (describing a program usirig non-lawyer volunteers backed up by lawyers), this Comment is based on the premise that the child's voice must be one "guided by relevant legal tradition and principles." Bross, supra note 54 , at 85 . The child's advocate must handle the maze of legal rules in order to "facilitate the legal process so that the child is not damaged or compromised by a system whose goals should be to protect the child, but which . . . may ... lose sight of the child's needs and capacities." Goldson, supra note 36, at 17-18.

A tension between social work and law is unavoidable in this context. Each has its role for the child and, in the ideal situation, there will be an attorney advocate and 
We are, first, lawyers charged with representing clients. ... [E]ven though our client may be young, when he or she is capable of exercising minimal judgment we will represent the client's position to the court. ... We will not represent a position to the court that is contrary to our client's wishes. . . . We do not believe that it is appropriate for [us] to assume the function of the court $\ldots .{ }^{57}$

The court ultimately is responsible for the child's best interests: "the trial court does not function solely as an arbiter between . . . private parties [but must] determine what ... would best guarantee an opportunity for the children involved to grow [in]to mature and responsible citizens." 58 A preliminary assessment by an advocate of these best interests usurps the judge's authority and prejudices the determination. While social and psychological expert testimony aids the judge in her determination of the child's "best interests," the child's voice must be heard and must inform any truly valid determination.

The child's advocate should represent only the interests of the child, and not consider the competing claims of the parents in the custody case. Once a parent's claim affects the representation, the child effectively has lost her advocate. For example, even when a child expresses terror and pleads with her "advocate" not to send her to an alleged abuser, the counsel who is affected by parents' concerns may fail to oppose visitation. ${ }^{59}$ In this scenario, what force does the child's voice really have? Who protects the child from the lawyer, and why have a lawyer at all? ${ }^{60}$

When the attorney is guided by her conception of a child's best interests and not by the voice of the child, interest conflicts or diminished representation may be overlooked. For example, in one paren-

a guardian ad litem. If there is only one representative, it ought to be the attorney, and the social worker can testify as a witness for the child as the American Bar Association has suggested. See infra notes 64-66.

57 Juvenile Law Center of Philadelphia, JLC Model of Representation in Dependent Court (draft Feb. 24, 1986).

58 Hansen, supra note 39, at 184 (quoting Kritzik v. Kritzik, 21 Wis. 2d 442, 124 N.W.2d 581 (1963)).

59 See, e.g., Apel, supra note 34, at 492-93 (containing an excellent chronology of the Morgan case); Hilary's Guardian: A Breach of Trust, Legal Times, Feb. 20, 1989, at 19 , col. 4 (letter to editor claiming that although empowered to cancel or interrupt visits, the guardian of Hilary Foretich, the child in the highly publicized MorganForetich case, did not do so despite the child's express wishes). This scenario is especially problematic because of the preference for keeping families and parentchild relationships intact. See infra note 80 and accompanying text.

60 See Juvenile Law Center of Philadelphia, supra note 57, at 2 (expressing concern that lawyers will "present a case that is contrary to a client's wishes"). 
tal rights termination proceeding where abuse was alleged, the "advocate of the child's best interests" standard permitted the dual representation of two children whose wishes were diametrically opposed. One child wanted to return to her mother while the other child did not. ${ }^{61}$ Because the children's counsel's role was to advocate the children's best interests, however, the Iowa Supreme Court found no "actual" conflict. ${ }^{62}$ Furthermore, because it was a juvenile proceeding, the court was unwilling to presume prejudice from the dual representation "even if under ordinary [criminal] standards a substantial possibility of conflict would be shown."63

Standards proposed jointly by the American Bar Association and the Institute for Judicial Administration expressly reject the traditional guardian ad litem model of representing children and urge advocacy of the child's interests. ${ }^{64}$ In protective proceedings "where the juvenile is capable of considered judgment on his or her own behalf, determination of the client's interest in the proceeding should ultimately remain the client's responsibility."65 The introduction to the Standards claims that this model of the lawyer-client relationship is necessary to achieve fundamental goals of the legal system, including enforcement of the child's substantive rights and facilitation of accurate determination of factual and legal issues through the adversary process. ${ }^{66}$

Whenever there is suspicion that children have been sexually abused, representation by an attorney acting as an advocate should be required. ${ }^{67}$ Any legislation requiring representation must clearly

61 See In re J.P.B. and C.R.B., 419 N.W.2d 387 (Iowa 1988) (claiming that the dual representation did not prevent the effective representation of the child who wished to remain with the petitioner).

62 See id. at 390.

63 Id. at 392.

64 See IJA-ABA Joint Commission on Juvenile Justice Standards, Standards Relating to Counsel for Private Parties Standard 3.1(a) (1976).

65 Id. at Standard 3.1(b)(ii)(b). However, the Standard continues that in cases involving "very young persons" the child

may be incapable of considered judgment, in which case responsibility passes to the guardian ad litem. If no guardian ad litem has been appointed, the attorney is to determine the child's interest after inquiring into all relevant circumstances or may elect to confine her role to fact finding only and take no position before the court.

Id. at Standard 3.1(b)(ii)(c) and comment.

66 See id. at 3-5 (introduction to standards).

67 See de Montigny v. de Montigny, 70 Wis. 2d 131, 138, 233 N.W.2d 463, 467 (1975) ("It is clear that a guardian ad litem appointed to represent children is more than a nominal representative appointed to counsel and consult with the trial judge. Rather, he has all the duties, powers, and responsibilities of counsel who represents a 
delineate the responsibility of the child advocate in order to provide all incest victims the voice needed to protect their interests.

\section{Addressing the Arguments Against Independent LEGAL REPRESENTATION}

\section{A. Parens Patriae}

Children in private custody battles where sexual abuse is alleged currently must rely on judicial discretion for independent legal representation. ${ }^{68}$ Parens patriae, a derivative of English common law, is often used as a spearhead against the use of children's advocates; the notion is that " $[\mathrm{t}]$ he king should protect all who have no other protector, that he is the guardian above all guardians .... The king's justices see no great reason why every infant should have a permanent guardian, because they believe that they can do full justice to infants." 69 Many judges believe that the parents' representatives and the "independent investigative powers and duties of the court . . . adequately protect the children's interests and renders unnecessary the extra expense and delay of cases by court appointment of counsel to independently represent the children."70 According to the parens patriae doctrine, children do not need independent legal representation because their interests are protected by the court itself. The legal system relies heavily on this premise. $^{71}$

As noted in a Bill of Rights for Children, it is an anomaly that children in any divorce proceeding are unrepresented. "The major disputed issue may be their custody and visitation rights, and in a very real sense, they may be the principal parties in interest since the ultimate issue . . . is their welfare and best interests."72 This argument has greater force when sexual abuse is alleged, because the court

party to litigation."); c.f. Vande Hoven v. Vande Hoven, 336 N.W.2d 366, 368 (N.D. 1983) (stating in dicta that where sexual abuse is alleged, "it appears to be in the best interests of the children to have their guardian ad litem bestowed with full advocacy authority"). Note that the court in Vande Hoven was operating under a statutory requirement that a guardian ad litem was to advocate the best interests. See N.D. CENT. CODE \& 14-09-06.4 (1981).

68 See supra notes 12-17 and accompanying text (describing the discretionary standard as the current state of the law).

69 II F. Pollock \& F. Martland, The History of English Law 445 (2d ed. 1899).

70 Chalupa v. Chalupa, 220 Neb. 704, 705-06, 371 N.W.2d 706, 707-08 (1985).

71 See Legal Rights of Children, supra note 7, at 677 n.14 (noting current American law).

72 Foster \& Freed, supra note 2, at 355. 
decides not only which parent will have custody but whether or not the child's body and mind will continue to be invaded. Regrettably, these children are legally no more entitled to a "voice" than children in any other custody dispute.

If the victim of incest is to realize her right to legal protection, her story must first be heard. ${ }^{73}$ As a Milwaukee family court judge who has instituted the appointment of guardians ad litem in all disputed custody cases has notied:

When two terriers fight over a bone, the bone does not join the fighting. But a child is not a thing or an object to go as a prize to the winner of a contest .... The whole future life of the child will be affected by the court's decision .... Will such basic interests of the child be adequately represented or even presented to the court by the attorneys for the warring litigants? ... Is not a minor and dependent child whose parents are involved in a divorce case entitled to ... representation [similar to that given to a child in a tort or probate action] at least in those cases in which custody becomes a matter of dispute between the parties or concern to the court? ${ }^{74}$

Judges who serve as protectors of children's social and legal interests sacrifice impartiality. ${ }^{75}$ The composite voices of social psychologists, physicians, parents, and young children upon which judges may rely cannot equal the autonomous legal voices of children themselves. ${ }^{76}$ Professor Laurence Tribe recognized the potential limits of wise and benevolent paternalism, stating:

If the universality of the childhood experience ... could guarantee empathy from adult lawmakers despite the absence of children from legislative assemblies, there would be no occasion to regard children as an isolated and unrepresented minority in need of special protection; but if adults instead look with contempt at a stage they have "outgrown" and will never re-enter, then every privilege withheld . . . from the young must become a source of suspicion. ${ }^{77}$

73 See id. ("The right to be heard includes the right to have standing in legal proceedings to assert one's claims of interest.").

74 Hansen, supra note 39, at 181-82.

75 See Isaacs, The Role of the Lawyer in Child Abuse Cases, in Helping the Battered Child and His Family 225, 229 (C. Kempe \& R. Helfer eds. 1972) ("Even the judge cannot adequately serve as protector of the legal ... interests of the child without seriously sacrificing the appearance of impartiality").

76 See Tribe, Childhood, Suspect Classifications, and Conclusive Presumptions: Three Linked Riddles, 39 Law \& ConTEMP. Probs. 8, 12 n.14 (Summer 1975) (stating that the basic message of In re Gault, discussed infra at notes 117-22 and accompanying text, is that "the best paternalistic intertions toward children cannot substitute for procedurally fair juvenile hearings").

77 Id. at 9 (footnote omitted). 
In order to ensure the vitality of the legal system, judges must recognize that today's children may view situations such as custody and visitation in unique and unprecedented ways. The need for an individualized voice is critical in this context because determinations are based on the best interests analysis, and society lacks a consensus regarding what is "best" for children. ${ }^{78}$ Thus, when the consequences of a disposition may be irreparably harmful, as in the case of sexual abuse, ${ }^{79}$ individualized children's voices must be heard. Independent legal representation that articulates the voice of each child is the best way to accomplish this objective.

\section{B. Familial Privacy}

Another obstacle to the independent representation of allegedly abused children in private custody cases stems from a perception of the American family as an autonomous "private government" with protected interests. ${ }^{80}$ Because children legally are incapable of determining what is in their best interests, and parents legally are presumed competent to represent their children's interests, appointing counsel for children is often seen as infringing on parental rights. ${ }^{81}$

Society protects the right of individuals to marry, ${ }^{82}$ to procreate or not to procreate, ${ }^{83}$ and, increasingly, to define themselves as

78 See id. at 27 (calling for individualization when the dissolving moral consensus affects agreed-upon fundamental rights, such as the circumstances warranting depriving a parent of the right to raise her child).

79 See supra note 36 (discussing the consequences of sexual abuse).

80 See Griswold v. Connecticut, 381 U.S. 479, 485-86 (1965) (reserving a constitutionally protected sphere of privacy within a family). The view of the family as a private "corporation" dictates that the state will do everything to support the unification of the family. Therefore, it is rare for a court to deny visitation rights even if there is known physical and sexual abuse of the child. See Domestic Violence on Trial: Psychological and Legal Dimensions of Family Violence 149 (D. Sonkin ed. 1987).

81 See J. Goldstein, A. Freud \& A. Solnit, supra note 48, at 9-14 (discussing the legal status of children); Guggenheim, The Right to be Represented But Not Heard: Reflections on Legal Representation for Children, 59 N.Y.U. L. REv. 76, $121-22$ (1984) (arguing that because the best interests test makes virtually all aspects of a parent's life relevant, a child advocate may probe into "deeply held secrets" which parents have privately agreed to keep out of the court's consideration).

82 See Zablocki v. Redhail, 434 U.S. 374, 383 (1978) (holding that the right to marry is fundamental).

83 See Griswold, 381 U.S. at $483-85$ (creating a marital privacy right derived from Bill of Rights guarantees). A drastically different approach would be to require state licensing of all prospective biological and adoptive parents. See LaFollette, Licensing Parents, 9 Philosophy and Public Afrairs 182 (1980) (supporting such licensing). 
"families" for many purposes. ${ }^{84}$ Families may protect themselves against state intrusion by invoking constitutionally protected rights of privacy. ${ }^{85}$ It is incongruous, however, to restrict the exercise of such rights to traditional family units while ignoring the individual rights of children from shattered families. ${ }^{86}$ The theory of the family as an inviolable unit presurnes that the family is intact and can be counted on to protect its members. ${ }^{87}$ When divorce and abuse disintegrate the family social unit, viewing the family as paramount may fail to protect the child. ${ }^{88}$

Parents embroiled in custody disputes involving allegations of abuse are particularly inappropriate representatives of their child's welfare or wishes. ${ }^{89}$ When one parent alleges sexual abuse by the other, the accused parent's judgment and parental fitness is ques-

84 See, e.g., Moore v. City of East Cleveland, 431 U.S. 494 (1977) (invalidating a housing ordinance which did not recognize a grandparent and grandchild as a "family," arbitrarily cutting off the protection of family rights at the boundary of the nuclear family); Smith v. Organization of Foster Families, 431 U.S. 816, 842-47 (1977) (suggesting that foster families have sufficient indicia of "family" to entitle them to some constitutional protection); Santa Barbara v. Adamson, $27 \mathrm{Cal}$. 3d 123, 610 P.2d 436, 164 Cal. Rptr. 539 (1980) (relying on a state constitutional privacy provision to strike down city zoning ordinance that defined family to exclude groups of more than five unmarried people); Braschi v. Stahl Assocs. Co., 74 N.Y.2d 201, 543 N.E.2d 49, 544 N.Y.S.2d 784 (1989) (holding that a homosexual relationship constitutes a "family" under New York City's rent-control regulations); Gutis, What Is A Family? Traditional Limits Are Being Redrawn, N.Y. Times, August 31, 1989, at C1, col. 5 (discussing Braschi and "domestic partnership laws," noting that as society changes, the definition of family also changes, and quoting Professor Robert F. Kelly: "the law is basically trying to catch up to these transformations in family structure").

85 See Richards, The Individual, the Family, and the Constitution: A Jurisprudential Perspective, 55 N.Y.U. L. Rev. I, 4 \& n.35 (1980).

86 See supra text accompanying note 72.

87 See Second Chances, supra note 2, at 17 (noting that the present understanding of child development and family life is almost entirely based on the intact family form).

88 See J. Goldstein, A. Freud \& A. Solnit, supra note 48, at 66 (stating that "the presumption [of parental representation] should not prevail ... once the child's placement becomes the subject of a dispute" taken to the courts and in other situations where there is no "conflict-free interest" in representing the child). In these cases, the child should be accorded party status and given independent representation. See id.; Inker \& Perretta, supra note 42, at 111 ; Podell, The "Why" Behind Appointing Guardians Ad Litem for Children in Divorce Proceedings, 57 MarQ. L. REv. 103, 103 (1973) (stating that the child of divorce is a "disenfranchised victim used as a pawn in a game of chess being played between its warring parents who frequently want the court to physically cut up and divide the child between them in the same manner that they have [done] emotionally").

89 See Lempp, Child Welfare and the Law: A Medical and Psychiatric Viewpoint, in The Child and THE LAw 213, 221 (F. Bates ed. 1976) (discussing the protection of children's interests in divorce actions). 
tioned. ${ }^{90}$ As an interested party, each parent should be presumed incapable of presenting a voice that contradicts his or her own. ${ }^{91}$ Neither parent can be relied upon to speak for the child; consequently, an extremely deferential approach to the parents is no longer viable. For this reason, the child's voice must be heard in order to procedurally protect her best interests. This need outweighs competing concerns. ${ }^{92}$ To assume that the parents' attorneys have covered the entire agenda ignores the reality that "in countless circumstances a juvenile's rights and interests . . . are at sharp variance with those of his parents."93 The possibility of abuse and allegations of such certainly constitute one of those circumstances. Indeed, "[w]ithout a separate advocate, the court may not perceive the existence of the special needs of the child."94

\section{LEgal Foundations FOR INDEPENDENT REPRESENTATION}

This Comment has argued that when sexual abuse is alleged, a statutory commitment to a best interests determination requires the procedural protection of independent legal representation for a child. In addition to the best interests rationale, reform in the private custody dispute context may be based on analogous statutory authority or on constitutional grounds. Ultimately, finding constitutional authority is less important ${ }^{95}$ than sensitizing courts and legislators to the need of every child for independent counsel when allegations of sexual abuse are asserted. In the end, however, judicial discretion is too slim a reed upon which to rest the right to be free from sexual molestation. Legislators have already recognized that when the state alleges abuse, a child must be provided represen-

90 See Bross, supra note 54, at 86.

91 See Redeker, supra note 52, at 527-28. Just as the rights of the parent or custodian and the rights of a child conflict in a child abuse action, so too does a conflict exist between the child and her parents in a custody suit where abuse is alleged. Just as the state is an "interested party" when it initiates abuse proceedings against a parent, parents suing for custody are also parties with interests distinct from the child's. See id.

92 cf. Podell, supra note 88, at 107 (dismissing parental objections to counsel as lacking merit in light of the child's interests). Arguments in favor of parental privacy rights rely heavily on the premise that both parents in a custody dispute are fit and, therefore, that a child without counsel faces only a small risk of damage. See Guggenheim, supra note 81, at 121-22. Continued sexual abuse by one of the parents obviously negates this underlying premise.

93 In re Clark, 21 Ohio Op. 2d 86, 87, 185 N.E.2d 128, 130 (1962).

94 Genden, supra note 14 , at 573 .

95 See id. at 581 (noting that avoiding constitutional issues may be advantageous as a matter of litigation strategy). 
tation. This right of representation must be extended to include the children in private custody disputes who are possible victims of abuse.

\section{A. Analogy to State-Initiated Investigations of Abuse}

When a state alleges abuse, the child who is the subject of the custody proceeding is generally statutorily guaranteed representation. Such a guarantee is strongly supported by the federal government, particularly in cases of child sexual abuse. ${ }^{96}$ The Child Abuse Prevention and Treatment $\mathrm{Act}^{97}$ conditions the granting of federal funds for the handling of child abuse cases on a state's provision of a guardian ad litem to represent the child in "every case involving an abused or neglected child which results in a judicial proceeding." 98 State statutes commonly require that when the state alleges abuse,

96 While it was once assumed that the judge, the attorney for the child's parents, and the attorney for the agency bringing proceedings were capable of adequately representing the child's interests, an "analysis of the roles and responsibilities of these attorneys shows that they cannot fully represent the interests of the child and that there is a clear and demonstrable need to provide the child with independent representation in abuse and neglect proceedings." NAT'L CENTER ON ChILd AbUSE \& Neglect, U.S. Dep't of Health \& Human Servs., Representation for the Abused and Neglected Child: The Guardian Ad Litem and Legal Counsel 2 (1980).

Congress has recognized that child abuse is a steadily increasing problem of significant national magnitude that imposes both social and economic costs on its victims and on society. See H.R. REP. No. 135, 100th Cong., 2d Sess. 18, 20-21, reprinted in 1988 U.S. CODE CONG. \& ADMIN. NEws 72, 75, 77. In recognition of the problem, Congress has acted to impose responsibilities on the states and federal government to monitor the effectiveness and facilitate the improvement of the independent legal representation of children in abuse cases. See, e.g., Child Abuse Prevention, Adoption, and Family Services Act of 1988, Pub. L. No. 100-294, 102 Stat. 102, 118 (codified as amended at 42 U.S.C.A. $\$ 5105$ note (West Supp. 1989)) (requiring the National Center on Child Abuse and Neglect to study the provisions of legal representation of children in each state as well as the effectiveness of such representation); id. at 113-16 (codified as amended at 42 U.S.C.A. $\$ 5106 c$ (c)-(e) (West Supp. 1989)) (requiring as a predicate for federal funding of the handling of child abuse cases, particularly cases of sexual abuse, that each state designate a task force whose recommendations must be adopted).

9742 U.S.C.A. \& 5101-07 (West 1983 \& Supp. 1989). The 1988 amendments to the Act seek to (1) improve the quality of the administration of the National Center on Child Abuse and Neglect; (2) strengthen the coordination of its efforts with other federal agencies to implement a unified approach to guide national priorities; (3) expand the activities to be performed with regard to the collection and dissemination of research and data; and (4) emphasize the importance of identification and prevention efforts. See H.R. REP. No. 135, supra note 96, at 22-25, reprinted in 1988 U.S. Code Cong. \& Admin. News 72, 78-82.

9842 U.S.C.A. $\$ 5106 \mathrm{a}(\mathrm{b})(6)$ (West Supp. 1989). The statute's effectiveness may be questioned given that it does not specify whether the guardian ad litem must be an attorney. 
the child must be provided with independent representation. ${ }^{99}$ The federal and state governments, however, have not extended this right to the many potentially sexually abused children in private custody disputes. Given Congress' express recognition of the importance of representation in sexual abuse cases brought by the state, the different treatment of children in private cases.is unjustified. Their interests are coextensive with those of children in state-initiated proceedings.

One might attempt to draw distinctions between sexual abuse proceedings initiated by the state and those which are not, in an effort to argue that the child's need for representation is less" critical in a private custody dispute. As demonstrated below, these distinctions are specious.

\section{The Veracity of Allegations Made in the Divorce "War"}

There is a commonly held assumption that allegations of sexual abuse made by "warring" spouses are more likely to be false than allegations made by a state agency. ${ }^{100}$ Based on this assumption, the need for procedural safeguards, such as independent representation, is perceived as less critical in private custody disputes. Recent studies have shown this assumption to be unfounded:

The number of sexual abuse charges arising during divorces and/or custody/visitation disputes are small in number, only a very small percentage of even the contested cases.

The number of cases involving such allegations has increased in recent years, as have sexual abuse reports in the general population....

At present, there is no evidence to suggest that allegations arising at the time of divorces or custody disputes are more likely to be false.

99 See, e.g., Alaska STAT. $\$ 47.17 .030$ (e) (1984) (providing for representation by a guardian ad litem); CAL. WELF. \& INST. CODE $\$ 326$ (West 1984) (making official who files petition alleging abuse the child's guardian ad litem); N.J. STat. ANN. § 9:6-8.23 (West 1976) (providing for appointment of law guardian in abuse cases); WIS. STAT. ANN. $\S 48.23(3 \mathrm{~m})(1987)$ (requiring appointment of counsel under certain conditions when abuse is alleged); see also Model Child Abuse \& Neglect Rep. Law § 15A (1975) (providing that child subject to any judicial proceeding regarding child abuse or neglect shall be entitled to legal counsel).

100 See Keating, supra note 34, at 113 (noting that the assumption may be attributed to society's belief that the allegations in such a situation are almost always false); Sege, Some Say Ruling Will Silence Other Women, Boston Globe, June 22, 1989, at 1 (stating that the percentage of true allegations of sexual abuse in private cases is similar to that in cases begun by child protective agencies). 
Deliberately false allegations made to influence the custody decision or to hurt an ex-spouse do happen but they are viewed by knowledgeable professionals as rarities. ${ }^{101}$

Society doubts the truthfulness of the allegations because " $[\mathrm{i}] \mathrm{t}$ is an easier psychological rationalization to believe that an ex-spouse would make up these charges to get even than it is to believe that a parent would molest his own child."102 Articles suggesting that children are frequently "brainwashed" by vindictive spouses to believe that they were molested, have misled legal and clinical decisionmakers. ${ }^{103}$ Because of feelings that allegations of abuse are likely to be false, courts may ignore such allegations in making custody determinations. ${ }^{104}$ This harms both the protective parent and the abused child. As one observer noted, "[w] hat we really need to be stressing to the legal and mental health community is to look at each case as an allegation of child sexual abuse and ignore the fact that there's a custody battle going on . . . . That, in and of itself, will probably tell you very little."105 Ensuring that the child's independent voice is heard is one method of counteracting misperception regarding abuse in custody disputes.

\section{Societal Stereotypes About Incest}

Distinguishing sexually abused children in private custody disputes from those in state-initiated proceedings also may be attributed to general reluctance to believe that incest sweeps across the socioeconomic spectrum. The tragic death of Lisa Steinberg in New York City chillingly illustrated that child abuse is not solely an incident of poverty or lack of education. ${ }^{106}$ The erroneous assumption

101 Keating, supra note 34, at 117 (quoting N. Thoennes \& J. Pearson, Summary of Findings from the Sexual Abuse Allegations Project 17-19 (1987) (unpublished paper prepared by the Research Unit of the Association of Family and Conciliation Courts, Denver, Colorado)).

102 Id. at 115.

103 See Letter from Graeme Hanson, M.D., to Melvin Lewis, M.D., editor, $27 \mathrm{~J}$. Am. Acad. Child \& Adolescent Psychiatry 258 (1988) (criticizing Green, True and False Allegations of Sexual Abuse in Child Custody Disputes, 25 J. Am. Acad. Chrnd \& ADOLEscent Psychiatry 449 (1986) (concerning fabrication and collusion)).

104 See Keating, supra note 34, at 113.

105 Sege, supra note 100 (quoting Nancy Thoennes, director of the Sexual Abuse Allegations Project in Denver).

106 Lisa Steinberg died after suffering extensive physical abuse at the hands of her stepfather, Joel Steinberg. Steinberg, an attorney, was convicted of first-degree manslaughter. See Sullivan, Steinberg Is Guilty of First-Degree Manslaughter, N.Y. Times, Jan. 31, 1989, at Al, col. 1 . 
that one can assess sex abusers by "type" 107 -education, wealth, or other socioeconomic factors-means that legislators and judges are less likely to view accusations levelled in the divorce context as truthful. ${ }^{108}$ When abuse proceedings are initiated by the state, they more typically involve parents and children of lower socioeconomic levels. Reporting patterns significantly obscure the economic and social distribution of child abuse. A poor family in a clinic or emergency room setting is far more likely to be suspected, evaluated, and reported than is an affluent family whose child is treated in a private practitioner's office. ${ }^{109}$ In less affluent neighborhoods, child protection agencies are more likely to learn of potential danger to the child, to force the family into the child protective system, and to provide the child with representation. In short, abuse, including sexual abuse, is less likely to be detected by the state if the family is of moderate or substantial economic means. As a result, some allegations of sexual abuse may come to the state's attention only when the parties are engaged in a custody dispute. Unfortunately for these children, their right to representation is often denied simply because their abuse is revealed during a private custody dispute. ${ }^{110}$

107 See Keating, supra note 34, at 120 ("Courts all too often base a decision solely on an evaluation of the accused parent. If he does not fit the profile of what the evaluating professional sees as the 'type' to molest children, the court does not deem it possible that he has molested the child.").

108 This is not to say that only people in higher socioeconomic clases have private custody disputes. Legislators and judges may be less likely to view accusations levelled in the divorce context as truthful not because fewer of the stereotypical high-risk abusers-the poor and the uneducated-are in divorce court, but because of the view that private custody proceedings are only a secondary, and therefore relatively unimportant, source of protection for abused children. Such a view sees abuse as occurring primarily in lower class families. According to this view, because such abuse is likely to be detected by state agencies, triggering representation at a judicial determination stage, there is little need for independent representation in the divorce context; the child's interests will be protected in the state-initiated proceeding.

109 See Kerns, supra note 36, at 24; see also Martin, The Child and His Development, in Helping the Battered Child, supra note 48, at 93, 93-94 (noting that a public child development center does not serve many middle- or upper-class families).

110 This result may be seen as discriminating against both the interests of the children of middle to upper economic means, whose voices are not heard, and against the parents of lower economic means, who are prosecuted with greater frequency. Is there any reason to provide better representation to the child in stateinitiated proceedings or to provide greater protection of privacy to wealthier parents? 


\section{B. Constitutional Authority}

Children clearly possess certain constitutional rights. ${ }^{11}$ The scope of these rights, however, is unclear. Professor Tribe has noted that children's rights, like those of "discrete and insular minorities," are difficult to safeguard because they are not represented in the legislature. ${ }^{112}$ Although there may be reasons to treat children differently from adults at times, children's rights prevail over competing considerations when

the issue ... involves the exercise of a right we have come to regard as constitutionally 'fundamental,' such as the right to bodily liberty or the right to be heard in one's own defense.... [W] [Wen such a right is at stake, the general fact of youth alone cannot automatically justify the right's abridgement. ${ }^{113}$

Sexual molestation is an invasion of bodily liberty and integrity. Just as a person has a right to refuse medical treatment ${ }^{114}$ and a right to be free from forced sterilization, ${ }^{115}$ each individual has the right to be free from incestuous sexual molestation. ${ }^{116}$ A child's right to

111 See, e.g., Planned Parenthood v. Danforth, 428 U.S. 52, 74 (1976) (holding that minors, as well as adults, are protected by the Constitution); Tinker v. Des Moines Indep. Community School Dist., 393 U.S. 503, 511 (1969) (holding that public school students have constitutionally protected freedom of speech); In re Gault, 387 U.S. 1, 13 (1967) (concluding that "whatever may be their precise impact, neither the Fourteenth Amendment nor the Bill of Rights is for adults alone"); Coe v. Gerstein, 376 F. Supp. 695, 698 (S.D. Fla. 1973) (stating that with reference to " 'fundamental', "personal,' constitutional rights," a pregnant woman under 18 years of age could not be distinguished from one of majority age), appeal dismissed, $417 \mathrm{U}$.S. 279 (1974); Genden, supra note 14, at 581 (discussing the nature of a child's constitutional rights).

Although the rights of children now appear to be firmly established, constitutional protection for cliildren is a fairly recent development. The first Supreme Court case involving the rights of children was not heard until 1966. See Kent v. United States, 383 U.S. 541, 561-62 (1966) (holding that due process entitles a juvenile to representation by counsel).

112 See Tribe, supra note 76, at 9 (citing United States v. Carolene Prods. Co., 304 U.S. 144, 153 n.4 (1938)).

113 Id. at 11.

114 See Tune v. Walter Reed Army Medical Hosp., 602 F. Supp. 1542 (D.D.C. 1985); Superintendent v. Saikewicz, 373 Mass. 728, 370 N.E.2d 417 (1977); Schloendorff v. Society of New York Hosp., 211 N.Y. 125, 105 N.E. 92 (1914), overruled on other grounds, Bing v. Thunig, 163 N.Y.S.2d 3, 143 N.E.2d 3 (1957).

115 See Skinner v. Oklahoma, 316 U.S. 535 (1942).

116 It is acknowledged that the threat to bodily integrity is not state initiated and that the fourteenth amendment applies only to state actors or those acting under the color of state authority. See The Civil Rights Cases, 109 U.S. 3, 11 (1883) (stating that only state actions are the subject matter of the fourteenth amendment). Even when parents agree on custody, however, the court's approval of this determination is a prerequisite to its validity. In deciding whether to approve the agreement, the 
be heard in "self-defense" is as critical a protective measure in a sexual abuse case as in a juvenile delinquency proceeding. All children who are suspected sexual abuse victims and who are the subjects of private custody disputes have important interests which are weighty enough to warrant explicit consideration in a constitutional analysis.

A due process argument that children in divorce custody cases are constitutionally entitled to representation may be based on In re Gault. $^{117}$ This landmark case established a minor's right to counsel in juvenile delinquency proceedings which may result in commitment to an institution. ${ }^{118}$ While the Court limited its decision to a determination of a juvenile's entitlement to counsel in delinquency proceedings, ${ }^{119}$ the case has been the impetus for extending the legal rights of minors. ${ }^{120}$

Ordinarily, the requirements of procedural due process apply only when there is a threat to life, liberty, or property, as protected by the fourteenth amendment. ${ }^{121}$ Gault expressed such a strong belief in the critical role of counsel in the American judicial system, however, that many commentators have argued that the right of counsel in Gault is independent of the type of interest affected. They assert that this right will eventually extend beyond those cases involving a deprivation of liberty to all judicial proceedings involving children. ${ }^{122}$

In any case, a child has a liberty interest in remaining in her family's custody. The Supreme Court has recognized that family

state also may be adjudicating whether abuse will continue; that decision will be enforceable by the state against the parties. See Bergstrom v. Bergstrom, $478 \mathrm{~F}$. Supp. 434, 439 (D.N.D. 1979) (holding that enforcement of a court custody order invoked the full powers of the District of Columbia, sufficient to meet the "federal action" requirement, the analog of state action, of the fifth amendment), vacated on other grounds, 623 F.2d 517 (8th Cir. 1980).

117387 U.S. 1 (1967).

118 See id. at 41 . The extent to which the opinion depends on the juvenile's interest in freedom from confinement is unclear. See infra notes 121-22 and accompanying text.

119 See Gault, 387 U.S. at 13-14.

120 See Bersoff, Representation for Children in Custody Decisions: All that Glitters is not Gault, 15 J. FAM. L. 27, 27 (1976-77) (attributing to Gault a general "alteration of the balance of power in child-populated, adult-dominated institutions," such as juvenile courts, schools, and mental hospitals).

121 See Board of Regents v. Roth, 408 U.S. 564, 569 (1972).

122 See, e.g., Genden, supra note 14, at 582 (discussing the extension of Gault); Inker \& Perretta, supra note 42, at 113 (stating that a dynamic system would logically extend the protections of Gault to all proceedings involving children); Due Process, supra note 9, at 177 (stating that Gault was the Court's recognition that children are not best served by informal treatment in a paternalistic system). 
relationships are interests which entitle parents to due process. ${ }^{123}$ The Court has also stated that liberty encompasses the right to establish a home, bring up children, and to "enjoy those privileges long recognized at common law as essential to the orderly pursuit of happiness."124

Just as a parent's liberty is affected by state decisions concerning her relationship with her child, a child's liberty is similarly affected. Therefore, the liberty interests of both the parent and the child must be protected by due process of law. The Second Circuit noted this reciprocity of rights in stating:

This right to the preservation of family integrity encompasses the reciprocal rights of both parent and children. It is the interest of the parent in the "companionship, care, custody and management of his . . c children ... and of the children in not being dislocated from the emotional attachments that derive from the intimacy of daily association," with the parents. ${ }^{125}$

A child's right to representation is derived from this right to continued parental contact, and its exercise guards against unnecessary disruption of parent-child relationships. In the context of stateinitiated custody proceedings, it has been recognized that: "[t]he physical liberty interest of a child in a neglect proceeding is sufficiently similar to the liberty interest of a child in a delinquency proceeding to require the same right to counsel."126 Similarly, it has been noted that: "[a] change of parental bondage during the tender years is hardly less upsetting of one's pattern of life than is the denomination and possible commitment of a child as a 'juvenile delinquent.'"127 While the representation of allegedly abused chil-

123 See Stanley v. Illinois, 405 U.S. 645,651 (1972) (stating that a parent's interest in the care, companionship, and custody of children are rights deserving of due process); Armstrong v. Manzo, 380 U.S. 545, 550 (1965) (requiring notice and a hearing before depriving a parent of the custody of a child).

124 Meyer v. Nebraska, 262 U.S. 390, 399 (1923).

125 Duchesne v. Sugarman, 566 F.2d 817, 825 (2d Cir. 1977) (citing Stanley, 405 U.S. at 651); See also Smith v. Organization of Foster Families for Equality and Reform, 431 U.S. 816, 844 (1977) ("No one would seriously dispute that a[n] . . interdependent relationship [exists] between an adult and a child in his or her care"); Smith v. Fontana, 818 F.2d 1411, 1418 (9th Cir. 1987) ("companionship and nurturing interests of parent and child in maintaining tight familial bond are reciprocal"); In re S.A.D., 382 Pa. Super. 166, 175, 555 A.2d 123, 126 (1989) (recognizing the child's interest in a dependency hearing as concomitant to the parents' rights).

126 Long, When the Client is a Child: Dilemmas in the Lawyer's Role, $21 \mathrm{~J}$. FAM. L. 607, 628 (1982-83).

127 Brown v. Chastain, 416 F.2d 1012, 1027 (5th Gir. 1969) (Rives, J., 
dren in state-initiated proceedings is governed by statutes, it is frequently argued that such a procedure is constitutionally compelled. ${ }^{128}$ If resting on constitutional grounds, the right ought to extend to private proceedings as well. The child's interest in a continuing relationship with a non-abusive parent is no less important when another parent, rather than the state, seeks effectively to terminate the relationship.

In all private custody disputes, cognizance of the constitutionally protected interest in family integrity begs the question of whether all children have a constitutionally protected right to be free from state interference with an ongoing parent-child relationship. Arguably, the court has no authority to inhibit a child's relationship with a non-custodial parent unless that relationship would cause the child articulable harm. ${ }^{129}$ One commentator has suggested that even when the institutionalization or foster care of a child is not contemplated, the child's liberty is always invoked by a change in custody, because of the potential deprivation to the child of the company and control of one parent. ${ }^{130}$ While a child does not normally have the liberty to choose her custodian, when a situation arises which calls for a judicial choice, failure to consider the child's

dissenting) (asserting the importance of not denying access to the courts because of statutory financial burdens).

128 See Inker \& Perretta, supra note 42, at 116-19; Redeker, supra note 52, at 530; Due Process, supra note 9, at 184 . The Constitutional basis of a child's right to counsel in this context is an open question in view of Lassiter v. Department of Soc. Serv., 452 U.S. 18 (1981) (holding that the due process clause did not require the appointment of counsel for the parent in every case in which parental rights may be terminated). When sexual abuse is alleged in the private dispute, the termination of visitation, as well as custody, is sought.

129 See 4 L. Wardle, C. Blakesley \& J. Parker, Contemporary Family LaW $\S 39: 12$, at 91 (1988). Refusing to protect a child's relationship with either single parent is inconsistent with expanding definitions of family. Cf. supra note 84 and accompanying text.

130 See Due Process, supra note 9, at 180-181 \& n.32 (recognizing that any change in custody, whether the child is removed to an institution or is shifted between parents, affects the same interests of the child and that there should be no distinction drawn for due process purposes). The child's interest has been viewed not merely as liberty, but as " $t]$ he basic human right to maintain and enjoy the relationship which normally exists between the parents and the children." State v. Wade, 19 Or. App. 314, 319, 527 P.2d 753, 755 (1974) (affording independent counsel to children involved in proceedings regarding the termination of parental rights), overruled on other grounds, In re D., 24 Or. App. 601,547 P.2d 175, cert. denied, 429 U.S. 907 (1976); see also Genden, supra note 14, at 581 (discussing the characterization of the interests in Wade). 
voice is arguably a derial of liberty under the fourteenth amendment. ${ }^{131}$

When sexual abuse is alleged, however, the liberty interests implicated are yet greater than those in general private custody disputes. Because a parent-child relationship is far more imperilled when sexual abuse is alleged, the child's liberty interest merits the same procedural safeguards in such cases as in state-initiated proceedings. While the potential for harm is generally less in private custody cases than in juvenile delinquency cases, this is not true of private custody cases in which sexual abuse is alleged. All allegations of child sexual abuse raise the need for the procedural protection of independent counsel to represent the suspected victims.

\section{CONCLUSION}

The nation has declared war on the critical social problem of child abuse, particularly sexual abuse. Because establishing sexual abuse in private custody disputes is so complex and difficult, and because the consequences of erroneous determinations are so pernicious, an attack on child abuse which does not include the private forum is incomplete.

In private custody disputes, the child's dual interests in avoiding continued molestation and in maintaining healthy relationships with non-abusing parents merit legal recognition. Because those interests differ from the parents' and are insufficiently protected by parens patriae, they warrant separate legal representation.

Whether or not it is recognized as constitutionally compelled, the present statutory and judicial commitment to making custody determinations that are in a child's best interests mandates the independent legal representation of all children when sexual abuse is alleged. This will not eradicate the damage done to victims of sexual

181 See Due Process, supra note 9', at 180; see also Brown v. Chastain, 416 F.2d 1012, 1027 (5th Cir. 1969) (Rives, J., dissenting) (professing that because a well-founded parental relationship is a necessity in that the formation of life habits is at stake, "there could hardly be a better case for Fourteenth Amendment protection"), cert. denied, 397 U.S. 951 (1970); $ø$. Hannah v. Larche, 363 U.S. 420, 442 (1960) (stating that "whether the Constitution requires that a particular right [of due process] obtain in a specific proceeding depends upon a complexity of factors," including the nature of the alleged right, the nature of the proceeding, and the possible burden on the proceeding). Custody proceedings will have great effects on the later lives of the children involved. In light of these effects, the flexible approach articulated in Hannah indicates that the due process right of independent legal representation should be provided to children in custody proceedings. See Inker \& Peretta, supra note 42 , at $116-18$. 
abuse; it can, however, provide a means for reducing the damage by insuring that the victim's interests are not neglected.

"The legal profession is the one most identifiable group in control of our nation's destiny. It must lead the way in providing for the needs of helpless children whose lives are tangled in the law."132 The independent legal representation of all children who are suspected victims of sexual abuse is a vital step towards tipping the scales of justice in the children's best interests. 


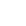

